\title{
Selection of Video on Demand Service Applications for Students Using TOPSIS
}

\section{Pemilihan Aplikasi Layanan Video on Demand bagi Mahasiswa Menggunakan TOPSIS}

\author{
Wandhansari Sekar Jatiningrum ${ }^{1 *}$, Setya Khusna Rossy Pertiwi ${ }^{1}$, Mohamad Irvan Irianto ${ }^{1}$, Yolanda \\ Okta Ria ${ }^{1}$ \\ ${ }^{1}$ Program Studi Teknik Industri, Fakultas Teknologi Industri, Universitas Ahmad Dahlan \\ Jalan Ringroad Selatan, Kragilan, Tamanan, Banguntapan, Bantul, 55164 \\ email :wandhansari.sekar@ie.uad.ac.id \\ doi: https://doi.org/10.31315/opsi.v14i2.4846
}

Received: 15 th June 2021; Revised: $26^{\text {th }}$ July 2021; Accepted: $5^{\text {th }}$ August 2021;

Available online: $21^{\text {st }}$ December 2021; Published regularly: December 2021

\begin{abstract}
The COVID-19 pandemic has forced people to do many activities at home. One of the most popular entertainment activities at home is watching a wide selection of dramas and films through the Video on Demand (VoD) service. People can choose various of VoD service applications with different characteristics. Therefore, the competition among VoD service applications has become increasingly high. If they are unable to keep up with market preferences, consumers may leave them. As the largest consumers of the film and drama industry, students have various factors to be considered in choosing alternatives to these streaming services. This study aims to enable users, namely students, to choose the best alternative among various choices of streaming service applications by considering several factors at once. TOPSIS method (Technique for Others Reference by Similarity to Ideal Solution) is used in this research to rank streaming service applications according to user preferences. The criteria considered by users are subscription fees, a variety of film and drama choices, application views, and services provided. Data collection was carried out by distributing questionnaires to 50 student respondents regarding the criteria and alternatives. The results of TOPSIS analysis showed that students prefer Viu application as the best choice for watching films and dramas. The second to fourth rankings are iflix, Netflix, and WeTV, respectively.
\end{abstract}

Keywords: TOPSIS; decision analysis; MCDM; streaming service applications

\begin{abstract}
ABSTRAK
Pandemi COVID-19 mengharuskan masyarakat untuk banyak beraktivitas di rumah. Salah satu hiburan yang banyak dilakukan yaitu dengan menonton berbagai pilihan drama dan film melalui layanan Video on Demand (VoD). Masyarakat dapat memilih berbagai aplikasi layanan VoD tersedia dengan pelayanan dan keunggulan yang berbeda. Hal ini menyebabkan persaingan antar aplikasi layanan VoD menjadi semakin tinggi. Apabila tidak mampu mengikuti selera pasar maka konsumen bisa saja meninggalkan aplikasi layanan tersebut. Mahasiswa sebagai konsumen terbesar industri film maupun drama memiliki berbagai faktor khusus yang dipertimbangkan dalam memilih aplikasi layanan streaming tersebut. Penelitian ini bertujuan agar pengguna yaitu mahasiswa dapat memilih alternatif terbaik di antara berbagai pilihan aplikasi layanan streaming dengan mempertimbangkan beberapa faktor sekaligus. Penelitian ini menggunakan metode TOPSIS (Technique for Others Reference by Similarity to Ideal Solution) yang akan menghasilkan peringkat aplikasi terbaik sesuai dengan keinginan pengguna. Kriteria yang dipertimbangkan oleh pengguna adalah biaya berlangganan, variasi pilihan film dan drama, tampilan aplikasi, dan pelayanan yang diberikan. Pengumpulan data dilakukan dengan menyebarkan kuesioner kepada 50 responden mahasiswa berkaitan dengan kriteria dan alternatif yang tersedia. Hasil dari analisis TOPSIS menunjukkan bahwa mahasiswa lebih memilih aplikasi Viu sebagai pilihan terbaik
\end{abstract}


untuk menonton drama dan film. Untuk peringkat kedua hingga keempat secara berturut-turut adalah iflix, Netflix, dan WeTv.

Kata Kunci: TOPSIS; analisis keputusan; film dan drama; aplikasi layanan streaming

\section{PENDAHULUAN}

Streaming merupakan suatu teknologi yang berfungsi untuk memutar audio atau video secara langsung dengan menggunakan jaringan, baik jaringan internet maupun lokal (Ramadhan, Virgono and Wahidah, 2009). Saat ini teknologi streaming berkembang pesat karena teknologi streaming sangat memudahkan seseorang untuk memainkan file audio atau video meskipun berada disuatu tempat yang jauh, asal terkoneksi dengan jaringan internet.

Berkembangnya teknologi streaming memungkinkan inovasi baru di dunia broadcast hingga teknologi mobile. Salah satu teknologi streaming yang populer saat ini yaitu Video On Demand. Video on Demand (VoD) merupakan sistem penyampaian dari suatu konten video online dengan menggunakan versi premium. Mekanismenya adalah konsumen harus melakukan pembayaran untuk berlangganan atau membayar sesuai dengan konten yang ingin dilihat. Menurut hasil survey yang dilakukan oleh Daily Social dengan Jakpat terhadap 1037 pengguna smartphone yang tersebar di Indonesia, sebagian besar responden telah mengetahui VoD. Hasil survey menunjukkan $51,21 \%$ responden mengetahui $\mathrm{VoD}$ merupakan video yang dapat dilihat melalui internet dan $49,66 \%$ responden menyampaikan pada VoD konsumen harus membayar sesuai dengan video yang dipilih untuk ditonton. Sekitar 70\% responden menyadari keuntungan berlangganan VoD. Dengan adanya VoD ternyata cukup mempengaruhi kebiasaan responden dalam melihat konten video. Sebanyak 58,68\% responden menyatakan bahwa sekarang menjadi lebih suka menonton dengan menggunakan smartphone dan komputer (Eka, 2017)

Selama pandemi COVID-19, 66\% masyarakat Indonesia memilih aplikasi hiburan untuk melakukan aktivitas online (Nabila, 2020a). Di antara aktivitas online yang dilakukan yaitu memilih aplikasi streaming video sebanyak $63 \%$. Oleh karena itu terjadi peningkatan aktivitas streaming. Contohnya saja Netflix yang berhasil mendapatkan sebanyak 15,77 juta pelanggan berbayar baru pada kuartal pertama di tahun 2020. Kenaikan ini meningkat
22,8\% dibandingkan tahun lalu (Kaonang, 2020).

Pengguna terbesar dari layanan $\mathrm{VoD}$ ini adalah mahasiswa (Hasan, 2017). Pada umumnya mahasiswa menggunakan layanan ini sebagai sarana hiburan di sela kesibukan kuliah. Kondisi pandemi COVID-19 yang menyebabkan banyak aktivitas yang harus dilakukan di rumah menyebabkan banyak mahasiswa memilih menghabiskan waktu untuk menikmati layanan VoD. Berbagai aplikasi layanan streaming $\mathrm{VoD}$ beredar di pasaran dengan karakteristik yang berbeda. Setiap jenis aplikasi layanan streaming memiliki keunggulan masing-masing. Mahasiswa sebagai salah satu segmen terbesar layanan tersebut memiliki berbagai faktor yang dipertimbangkan dalam memilih layanan VoD yang sesuai bagi mereka.

Hasan (2017) melakukan analisis terhadap faktor-faktor yang mempengaruhi minat untuk berlangganan pada layanan VoD netflix. Penelitian yang dilakukan terbatas pada layanan aplikasi netflix saja. Padahal banyak layanan aplikasi yang tersedia dan dapat dipilih oleh konsumen. Yusuf \& Indrawati (2019) melakukan penelitian serupa yaitu menganalisis faktor yang mempengaruhi untuk membentuk minat berlangganan pada industri $\mathrm{VoD}$ di Indonesia dengan model UTAUT2. Penelitian ini terbatas pada faktor-faktor yang dipertimbangkan oleh konsumen saja dalam memilih layanan aplikasi VoD tetapi belum memberikan rekomendasi alternatif layanan yang sebaiknya dipilih.

Tersedianya berbagai pilihan alternatif keputusan dengan berbagai faktor yang perlu dipertimbangkan termasuk dalam permasalahan pengambilan keputusan multi kriteria. Menurut Mulliner, Smallbone, \& Maliene (2013), Multi Criteria Decision Making (MCDM) adalah seperangkat metode yang digunaka untuk mengevaluasi sejumlah alternatif yang banyak, seringkali bertentangan, dan juga mempertimbangkan banyak kriteria. Salah satu metode dalam MCDM adalah TOPSIS yang menggunakan prinsip yaitu alternatif terbaik mempunyai jarak yang terdekat dari solusi ideal positif dan jarak yang terjauh dari solusi ideal negatif (Zavadskas et al., 2016). Berbagai 
alternatif aplikasi layanan VoD yang tersedia, membuat mahasiswa sebagai konsumen perlu melakukan pemilihan alternatif terbaik. Untuk itu analisis dengan metode TOPSIS perlu dilakukan untuk mengetahui rekomendasi alternatif keputusan terbaik yang dapat diambil mahasiswa berkaitan dengan layanan aplikasi VoD dengan mempertimbangkan beberapa kriteria sekaligus.

\section{METODE}

Objek penelitian ini adalah mahasiswa di kota Yogyakarta yang merupakan pengguna layanan VoD. Wawancara dan studi literatur dilakukan untuk menetapkan sejumlah alternatif layanan $\mathrm{VoD}$ dan sejumlah kriteria yang dipertimbangkan dalam pemilihan tersebut. Berdasarkan wawancara, aplikasi VoD Netflix, Iflix, Viu, dan WeTV adalah yang paling banyak digunakan. Untuk kriteria yang dipertimbangkan adalah sebagai berikut :

1. Biaya berlangganan, yaitu biaya yang harus dibayarkan oleh konsumen untuk menikmati layanan dalam setiap periode waktu. Harga yang diterima konsumen ini terbukti berpengaruh terhadap niat beli konsumen (Cheng, 2017)

2. Variasi pilihan konten, banyaknya pilihan konten tersedia, seperti film atau drama. Menurut Hasan (2017), content richness dapat memengaruhi keinginan seseorang utuk menggunakan media tersebut berdasarkan variasi konten tersedia

3. Tampilan aplikasi, penampilan fisik dari aplikasi. Tampilan fisik untuk pelayanan elektronik seperti estetika desain web, kemudahan penggunaan, dan visualisasi terbukti berpengaruh terhadap kepuasan pengguna (Moon, 2013)

4. Layanan yang diberikan, berbagai bentuk aktivitas yang diberikan oleh aplikasi untuk memberi kepuasan pelanggan.

Tabel 1 menunjukkan kriteria yang dipertimbangkan dalam pemilihan aplikasi layanan VoD dan alternatif aplikasi VoD yang tersedia.

Kuesioner dibuat untuk melihat tingkat kepentingan setiap kriteria dan tingkat kepuasan terhadap setiap alternatif layanan VoD berdasarkan setiap kriteria. Pilihan jawaban responden untuk setiap kriteria dan alternatif dapat dilihat pada Tabel 2.
Tabel 1. Kriteria dan alternatif pemilihan

\begin{tabular}{ll}
\hline \multicolumn{1}{c}{ Kriteria } & \multicolumn{1}{c}{ Alternatif } \\
\hline C1: Biaya berlangganan & A1: Netflix \\
C2: Variasi pilihan konten & A2: Iflix \\
C3: Tampilan aplikasi & A3: Viu \\
C4: Layanan yang diberikan & A4: WeTv \\
\hline
\end{tabular}

Tabel 2. Ranking kecocokan kriteria dan alternatif

\begin{tabular}{ll}
\hline \multicolumn{1}{c}{ Penilaian kriteria } & \multicolumn{1}{c}{ Penilaian alternatif } \\
\hline 1: Sangat Tidak Penting & 1: Sangat Tidak Baik \\
2: Tidak Penting & 2: Tidak Baik \\
3: Netral & 3: Netral \\
4: Penting & 4: Baik \\
5: Sangat Penting & 5: Sangat Baik \\
\hline
\end{tabular}

Pengumpulan data dilakukan melalui penyebaran kuesioner terhadap total 50 responden mahasiswa pengguna layanan VoD. Hasil kuesioner dari seluruh responden akan dirata-rata dengan rataan aritmetik sebelum masuk ke dalam pengolahan data.

Analisis yang dilakukan, yaitu menggunakan metode TOPSIS untuk mendapatkan urutan prioritas alternatif layanan VoD yang dipilih oleh pengguna. Menurut Widianta dkk. (2018), langkah-langkah yang diperlukan dalam pengerjaan metode TOPSIS, yaitu :

1. Membuat matriks keputusan yang ternomalisasi.

Untuk membuat matriks keputusan ternormalisasi perlu dilakukan kinerja ternormalisasi, seperti ditunjukkan pada persamaan (1)

$$
\mathrm{r}_{\mathrm{ij}}=\frac{\mathrm{x}_{\mathrm{ij}}}{\sqrt{\sum_{\mathrm{i}=1}^{\mathrm{m}} \mathrm{x}_{\mathrm{ij}}^{2}}}
$$

Dengan $\mathrm{r}_{\mathrm{ij}}$ merupakan ranking kinerja alternatif $i$ berdasarkan kriteria $j$ dan $m$ serta $\mathrm{n}$ adalah jumlah alternatif dan jumlah kriteria. Untuk i bernilai dari $1,2, \ldots, \mathrm{m}$ dan $\mathrm{j}$ bernilai dari $1,2, \ldots, n$.

2. Membuat matriks keputusan ternormalisasi berbobot.

Matriks keputusan ternormalisasi terbobot atau $\mathrm{y}_{\mathrm{ij}}$ diperoleh dari perkalian matriks keputusan ternormalisasi dengan bobot preferensi dari responden seperti terlihat pada persamaan (2). Bobot preferensi atau $\mathrm{w}_{\mathrm{i}}$ ini merupakan hasil kuesioner tingkat kepentingan kriteria yang diisi responden. 


$$
y_{i j}=w_{i} r_{i j}
$$

3. Mencari nilai matriks solusi ideal positif dan matriks solusi ideal negatif.

Solusi ideal positif A+ dan solusi ideal negatif A- dapat diperoleh dengan melihat dari ranking bobot ternormalisasi (yij), seperti ditunjukkan pada persamaan (3), dan (4)

$A^{+}=\left(y_{1}^{+}, y_{2}^{+}, \ldots, y_{n}^{+}\right)$

$A^{-}=\left(y_{1}^{-}, y_{2}^{-}, \ldots, y_{n}^{-}\right)$

Dengan ketentuan untuk $y_{j}^{+}$yaitu menggunakan nilai max $y_{i j}$ jika j merupakan atribut untuk keuntungan dan min $\mathrm{y}_{\mathrm{ij}} \mathrm{jika} \mathrm{j}$ merupakan atribut untuk biaya, sedangkan ketentuan untuk $y_{j}^{-}$yaitu menggunakan nilai $\min y_{i j}$ jika $j$ merupakan atribut untuk keuntungan dan max $y_{i j} j i k a j$ merupakan atribut untuk biaya.

4. Menentukan jarak antara nilai setiap alternatif dengan matriks solusi ideal positif dan negatif.

Jarak antara alternatif $\mathrm{V}_{\mathrm{i}}$ terhadap solusi ideal positif diapat diformulasikan sesuai dengan persamaan (5)

$$
D_{i}^{+}=\sqrt{\sum_{j=1}^{n}\left(y_{i j}-y_{i}^{+}\right)^{2}}
$$

Jarak antara alternatif $\mathrm{V}_{\mathrm{i}}$ terhadap solusi ideal negatif diapat diformulasikan sesuai dengan persamaan (6)

$$
D_{i}^{-}=\sqrt{\sum_{j=1}^{n}\left(y_{i j}-y_{i}^{-}\right)^{2}}
$$

5. Menentukan nilai preferensi pada setiap alternatif

Nilai preferensi pada setiap alternatif $\mathrm{V}_{\mathrm{i}}$ dapat dilihat pada persamaan (7).

$$
V_{i}=\frac{D_{i}^{-}}{D_{i}^{-}+D_{i}^{+}}
$$

\section{HASIL DAN PEMBAHASAN}

Pengumpulan data dari 50 kuesioner yang disebarkan, semua kuesioer kembali dan terisi secara lengkap. Hasil kuesioner dianalisis menggunakan metode TOPSIS, dengan tahapan sebagai berikut:

1. Membuat matriks keputusan yang ternomalisasi.

Berdasarkan hasil kuesioner berkaitan dengan penilaian kriteria dari semua responden, dilakukan perhitungan rata-rata nilai. Hasil bobot preferensi untuk setiap kriteria berdasarkan penilaian dari seluruh responden ditunjukkan pada Tabel 3.

Tabel 3. Bobot preferensi kriteria

\begin{tabular}{cc}
\hline Kriteria & Bobot \\
\hline C1 & 4,12 \\
C2 & 4,48 \\
C3 & 4,02 \\
C4 & 4,54 \\
\hline
\end{tabular}

Berdasarkan Tabel 3. diketahui bahwa bahwa kriteria $\mathrm{C} 4$ yaitu layanan yang diberikan mendapatkan penilaian yang paling tinggi yaitu sebesar 4,489. Menurut konsumen, layanan yang diberikan oleh aplikasi VOD sangat mempengaruhi kepuasan mereka. Untuk itu, tentu saja hal tersebut dapat berpengaruh terhadap pengambilan keputusan konsumen untuk memilih aplikasi layanan VOD. Layanan yang diberikan oleh setiap aplikasi VOD berbeda-beda. Transaksi pembelian layanan VOD terdiri dari dua jenis, yaitu dengan cara berlangganan atau berdasarkan konten yang ingin dilihat. Bahkan terdapat aplikasi VoD yang menawarkan layanan dengan memberikan 10 film untuk dapat ditonton gratis oleh konsumen, tanpa konsumen harus mendaftarkan akun terlebih dahulu. Kriteria dengan bobot preferensi terbesar selanjutnya adalah variasi konten. Layanan VoD dengan konten variatif, seperti film, drama, serial, reality show umumnya memiliki peminat yang tinggi karena konsumen dimudahkan untuk memilih konten yang sesuai dengan keinginan mereka.

Untuk hasil kuesioner penilaian konsumen berkaitan dengan alternatif aplikasi layanan VoD berdasarkan setiap kriteria dapat dilihat pada matriks keputusan yang ditunjukkan Tabel 4. Matriks keputusan yang terbentuk merupakan hasil rata-rata dari penilaian yang diberikan seluruh responden.

Tabel 4. Matriks keputusan

\begin{tabular}{ccccc}
\hline \multirow{2}{*}{ Alternatif } & \multicolumn{4}{c}{ Kriteria } \\
\cline { 2 - 5 } & C1 & C2 & C3 & C4 \\
\hline Netflix & 3,31 & 3,67 & 3,79 & 3,62 \\
iflix & 3,59 & 3,43 & 3,74 & 3,70 \\
Viu & 3,72 & 3,59 & 3,75 & 3,67 \\
WeTv & 3,45 & 3,62 & 3,51 & 3,51 \\
\hline
\end{tabular}

Berdasarkan tabel 4 terlihat bahwa penilaian tertinggi pada alternatif Netflix, Iflix, dan 
Viu adalah pada kriteria C3 atau tamplilan aplikasi, sedangkan penilaian pada alternatif WeTv yaitu unggul pada kriteria C2 atau variasi pilihan konten. Untuk penilaian paling tinggi dari semua alternatif yaitu pada alternatif Netflix berdasarkan kriteria tampilan aplikasi. Netflix juga menyediakan layanan yang memuat petunjuk untuk melakukan pengaturan tampilan aplikasi (Netflix, 2021). Hal ini menyebabkan konsumen merasa lebih nyaman dan mudah untuk mengatur tampilan aplikasi sesuai preferensi individu.

Matriks keputusan yang didapatkan kemudian dibuat dalam bentuk matriks keputusan yang ternormalisasi dengan berdasarkan pada persamaan (1). Tabel 5 menunjukkan matriks keputusan ternormalisasi.

Tabel 5. Matriks keputusan ternormalisasi

\begin{tabular}{ccccc}
\hline \multirow{2}{*}{ Alternatif } & \multicolumn{4}{c}{ Kriteria } \\
\cline { 2 - 5 } & $\mathrm{C} 1$ & $\mathrm{C} 2$ & $\mathrm{C} 3$ & $\mathrm{C} 4$ \\
\hline Netflix & 0,48 & 0,511 & 0,515 & 0,501 \\
iflix & 0,507 & 0,484 & 0,504 & 0,509 \\
Viu & 0,526 & 0,503 & 0,504 & 0,504 \\
WeTv & 0,485 & 0,503 & 0,475 & 0,485 \\
\hline
\end{tabular}

2. Membuat matriks keputusan yang ternormalisasi berbobot.

Setelah didapatkan matriks keputusan yang ternormalisasi, maka matriks tersebut dikalikan dengan bobot preferensi kriteria berdasarkan persamaan (2). Tabel 6 menunjukkan matriks keputusan ternomalisasi terbobot.

Tabel 6. Matriks keputusan ternormalisasi terbobot

\begin{tabular}{ccccc}
\hline \multirow{2}{*}{ Alternatif } & \multicolumn{4}{c}{ Kriteria } \\
\cline { 2 - 5 } & C1 & C2 & C3 & C4 \\
\hline Netflix & 1,976 & 2,288 & 2,070 & 2,276 \\
iflix & 2,09 & 2,167 & 2,028 & 2,313 \\
Viu & 2,17 & 2,252 & 2,028 & 2,288 \\
WeTv & 2 & 2,252 & 1,911 & 2,202 \\
\hline
\end{tabular}

Berdasarkan hasil pada tabel 6 , diketahui bahwa bobot pada kriteria layanan yang diberikan oleh Iflix memiliki nilai terbesar yaitu 2,313. Hal ini disebabkan kriteria layanan yang diberikan merupakan kriteria yang menjadi prioritas utama menurut konsumen, sedangkan Iflix merupakan aplikasi layanan VoD yang paling unggul dalam memberikan layanan menurut konsumen.

3. Menentukan matriks solusi ideal positif dan matriks solusi ideal negatif.

Berdasarkan persamaan (4) dan (5) maka didapatkan matriks solusi ideal positif $\mathrm{A}+$ dan matriks solusi ideal negatif A-

Matriks solusi ideal positif:

$\mathrm{Y} 1+=\max (1,976 ; \quad 2,090 ; \quad 2,169 ; \quad 1,999)=2,168$

$\mathrm{Y} 2+=\max (2,288 ; 2,167 ; 2,252 ; 2,252)=2,288$

$\mathrm{Y} 3+=\max (2,070 ; 2,028 ; 2,028 ; 1,911)=2,070$

$\mathrm{Y} 4+=\max (2,276 ; 2,313 ; 2,288 ; 2,202)=2,313$

Sehingga $\mathrm{A}+=(2,168 ; 2,288 ; 2,0702,313)$

Matriks solusi ideal negatif:

$\mathrm{Y} 1+=\max \quad(1,976 ; 2,090 ; 2,169 ; \quad 1,999)=1,976$

$\mathrm{Y} 2+=\max (2,288 ; 2,167 ; 2,252 ; 2,252)=2,167$

$\mathrm{Y} 3+=\max (2,070 ; 2,028 ; 2,028 ; \quad 1,911)=1,911$

$\mathrm{Y} 4+=\max (2,276 ; 2,313 ; 2,288 ; 2,202)=2,202$

Sehingga $A-=(1,976 ; 2,167 ; 1,911 ; 2,202)$

4. Menentukan jarak antara nilai setiap alternatif dengan matriks solusi ideal positif dan negatif.

Perhitungan jarak antara nilai terbobot setiap alternatif dengan matriks solusi ideal postif dan negatif dilakukan dengan menggunakan persamaan (6) dan (7) sehingga didapatkan:

a. Alternatif Netflix

$$
\begin{aligned}
& \mathrm{D}^{+}=0,197 \\
& \mathrm{D}^{-}=0,213
\end{aligned}
$$

b. Alternatif Iflix

$$
\mathrm{D} 2^{+}=0,151
$$$$
\mathrm{D} 2^{-}=0,197
$$

c. Alternatif Viu

$$
\mathrm{D}^{+}=0,061
$$

$\mathrm{D}^{-}=0,256$

d. Alternatif WeTv

$$
\begin{aligned}
& \mathrm{D}^{+}=0,261 \\
& \mathrm{D}^{-}=0,088
\end{aligned}
$$

Berdasarkan hasil perhitungan, diketahui bahwa jarak antara nilai terbobot dengan matriks solusi ideal positif pada alternatif Viu merupakan yang paling kecil dibandingkan dengan alternatif lain. Untuk jarak terbesar antara nilai terbobot dengan matriks solusi ideal negatif yaitu pada alternatif WeTv, dilanjutkan dengan Viu.

5. Menentukan nilai preferensi untuk setiap alternatif

Pada tahapan ini dilakukan perhitungan untuk kedekatan setiap alternatif terhadap 
solusi ideal menggunakan formulasi pada persamaan (8).

a. Alternatif Netflix

b. Alternatif Iflix

$$
V_{1}=\frac{0,213}{0,213+0,197}=0,52
$$

$$
V_{2}=\frac{0,197}{0,191+0,151}=0,566
$$

c. Alternatif Viu

$$
V_{3}=\frac{0,256}{0,256+0,061}=0,807
$$

d. Alternatif WeTv

$$
V_{4}=\frac{0,088}{0,088+0,261}=0,252
$$

Prinsip yang digunakan dalam TOPSIS yaitu alternatif terbaik merupakan alternatif yang memiliki jarak paling dekat dengan solusi ideal positif dan paling jauh dengan solusi ideal negatif berdasarkan sudut pandang geometris (Krohling and Pacheco, 2015; Yoon and Kim, 2017)(Yoon and Kim, 2017). Berdasarkan hasil perhitungan kedekatan setiap alternatif terhadap solusi ideal, didapatkan urutan preferensi konsumen untuk aplikasi layanan VoD adalah Viu $>$ Iflix $>$ Netflix $>$ WeTv. Hasil ini menunjukkan bahwa menurut konsumen Viu merupakan layanan VoD yang paling disukai berdasarkan kriteria biaya berlangganan, variasi pilihan konten, tampilan aplikasi, dan layanan yang diberikan. Menurut Nabila (2020b), Viu merupakan aplikasi penyedia layanan VoD berbayar yang populer dan mendapatkan antusiasme tinggi dari konsumen di Indonesia. Viu memiliki sejumlah keunggulan yang dapat dipertimbangkan oleh konsumen dalam memilih layanan VoD (Feb and Setyorini, 2019).

Hasil yang didapatkan menujukkan urutan kriteria dari skor tertinggi hingga terendah menurut responden adalah layanan yang diberikan, variasi pilihan konten, biaya berlangganan, dan tampilan tampilan aplikasi. Hal ini berarti bahwa layanan yang diberikan merupakan prioritas yang dipertimbangkan oleh konsumen dalam memilih aplikasi layanan VoD. Berbagai strategi dapat dilakukan untuk meningkatkan pelayanan kepada konsumen, di antaranya adalah pemberian layanan ekstra seperti potongan harga, tanggap dalam melayani pertanyaan atau keluhan konsumen, berada dekat dalam jangkauan konsumen, serta selalu menjaga dan meningkatkan kualitas produk yang ditawarkan.

\section{KESIMPULAN}

TOPSIS sebagai salah satu metode dalam MCDM terbukti mampu digunakan dalam analisis pemilihan layanan VoD. Hasil analisis dengan TOPSIS menunjukkan urutan preferensi konsumen untuk penggunaan aplikasi VoD adalah Viu $>$ Iflix $>$ Netflix $>$ WeTv dengan mempertimbangkan kriteria biaya berlangganan, variasi pilihan konten, tampilan aplikasi, dan layanan yang diberikan.

\section{DAFTAR PUSTAKA}

Cheng, L. P. (2017) 'Effects of Brand Image, Perceived Price, Perceived Quality, and Perceived Value on the Purchase Intention towards Sports and Tourism Products of the 2016 Taichung International Travel Fair', The Journal of International Management Studies, 12(2), pp. 97-107.

Eka, R. (2017) Video on Demand dan Penerimaannya oleh Masyarakat Indonesia. Available at: https://dailysocial.id/post/video-ondemand-dan-penerimaannya-olehmasyarakat-indonesia (Accessed: 3 October 2020).

Feb, M. and Setyorini, R. (2019) 'Pengukuran Kepuasan Pengguna Website viu.com dengan Menggunakan Pendekatan Webqual 4.0 dan Importance Performance Analysis', DINAMIKA EKONOMI Jurnal Ekonomi dan Bisnis, 12(1), pp. 33-50.

Hasan, V. A. (2017) 'Analisis Faktor-Faktor yang Mempengaruhi Willingnes to Subscrie: Telaah pada Layanan Video on Demand Netflix', Ultima Management, 9(1), pp. 22-38.

Kaonang, G. (2020) Jumlah Pelanggan Netflix Naik Drastis Selama Pandemi. Available at: https://dailysocial.id/post/jumlahpelanggan-netflix-naik-drastis-selamapandemi (Accessed: 3 October 2020).

Krohling, R. A. and Pacheco, A. G. (2015) 
'A-TOPSIS-an approach based on TOPSIS for ranking evolutionary algorithms', Procedia Computer Science, 55, pp. 308-317.

Moon, Y. J. (2013) 'The tangibility and intangibility of e-service quality', International Journal of Smart Home, 7(5), pp. 91-102. doi: 10.14257/ijsh.2013.7.5.10.

Mulliner, E., Smallbone, K. and Maliene, V. (2013) 'An assessment of sustainable housing affordability using a multiple criteria decision making method', Omega-International Journal of Management Science, 41(2), pp. 270279.

Nabila, M. (2020a) Menengok Sederet Aplikasi Hiburan Terpopuler Selama Pandemi. Available at: https://dailysocial.id/post/menengoksederet-aplikasi-hiburan-terpopulerselama-pandemi (Accessed: 3 October 2020).

Nabila, M. (2020b) Viu dan Netflix Bersaing Jadi Platform "Video on Demand" Berbayar Terpopuler di Indonesia. Available at: https://dailysocial.id/post/viu-netflixvideo-on-demand-berbayar-terpopulerindonesia (Accessed: 30 March 2021).

Netflix (2021) Netflix-Pusat Bantuan. Available at: https://help.netflix.com/en (Accessed: 30 March 2021).
Ramadhan, F., Virgono, A. and Wahidah, I. (2009) 'Desain Dan Implementasi Live Streaming Televisi Menggunakan Adaptive H264Encoding', in Seminar Nasional Informatika 2009. Yogya: UPN "Veteran" Yogyakarta, pp. 38-46.

Widianta, M. M. D. et al. (2018) 'Comparison of Multi-Criteria Decision Support Methods (AHP, TOPSIS, SAW \& PROMENTHEE) for Employee Placement', Journal of Physics: Conference Series, 953(1), pp. $1-5 . \quad$ doi: $10.1088 / 1742-$ 6596/953/1/012116.

Yoon, K. P. and Kim, W. K. (2017) 'The behavioral TOPSIS', Expert Systems with Applications, 89, pp. 266-272.

Yusuf, N. A. and Indrawati (2019) 'Analisis Faktor yang Mempengaruhi Minat Berlangganan di Industri Video on Demand di Indonesia', Almana : Jurnal Manajemen dan Bisnis, 3(1), pp. 161173.

Zavadskas, E. K. et al. (2016) Development of TOPSIS Method to Solve Complicated Decision-Making Problems - An Overview on Developments from 2000 to 2015 , International Journal of Information Technology and Decision Making. 